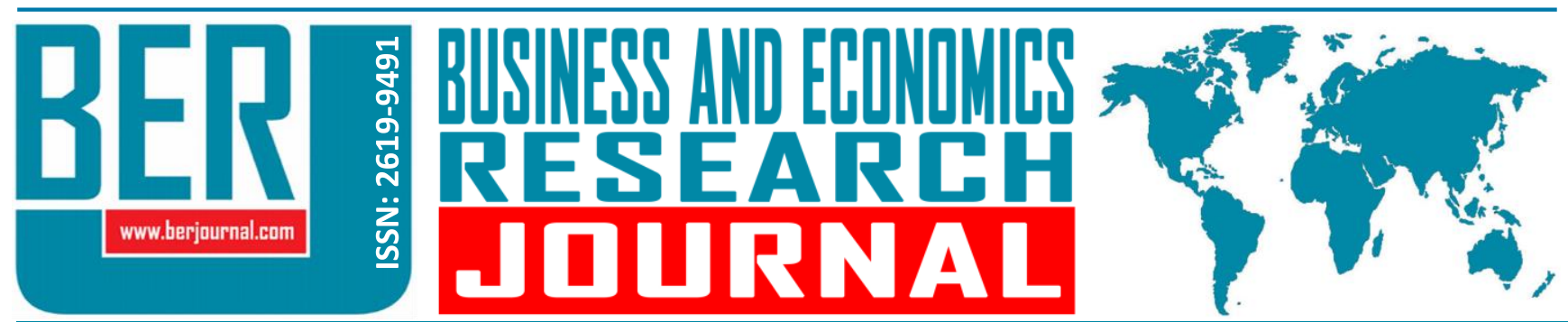

Business and Economics Research Journal Vol. 9, No. 3, 2018, pp. 681-696 doi: 10.20409/berj.2018.131

\section{Liderlik Davranışlarının Çalışanların Değişim Kapasitesine Etkileri: Bir Araştırma Çalışması}

\section{Ercan Ergun $^{a}$, Koray Yalcinkaya ${ }^{b}$}

Öz: Bu çalışmanın amacı, firmalarda gerçekleşen örgütsel değişimlerde liderlerin davranışlarının çalışanların değişim potansiyeline etkisini araştırmaktır. Araştırmanın örneklemini Kocaeli civarında faaliyet gösteren ve örgütsel değişimin gerçekleştiği 17 farklı firmada 140 çalışan oluşturmaktadır. Bu çalışanlardan anket tekniği ile toplanan veriler araştırma çerçevesinde analiz edilmiştir. Çalışmada liderlik davranışları boyutları ile çalışanların değişim kapasitesi boyutları arasındaki ilişkiler incelenmiştir. Araştırmanın bulgularına göre, yöneticilerin değişim sürecinde sergiledikleri liderlik davranışları ile çalışanların değişim potansiyeli arasında anlamlı bir ilişki olduğu saptanmıştır. Çalışmanın bulgularında, değişim odaklı liderlik davranışının çalışanın değişime açık olmasına ve duygusal hazır olmasına olumlu etki etmektedir. ilişki odaklı liderlik davranışının çalışanın değişime karşı bilişsel ve davranışsal hazır olmasına olumlu etkisi olmaktadır.

\section{The Effects of Leadership Behaviors on Employees' Change Capacity: A Research Study}

\begin{abstract}
The aim of this study is to investigate the effect of the behavior of leaders on the change potential of employees in organizational changes taking place at firms. The research data was collected from 140 employees in 17 manufacturing companies operating around Kocaeli Industrial Region performing organizational change. From these employees, the data collected by the questionnaire were analyzed in the research framework. The relationship between the dimensions of leadership behavior and the dimensions of change capacity of employees relations have been examined. The findings show that there is a significant relationship between change-oriented leadership behavior features open to change and emotional readiness of employees. Relationshiporiented leadership behavior is the highly important factor to increase of cognitive readiness and intentional readiness for change of employees.
\end{abstract}

Anahtar Sözcükler: Liderlik, Değişim, Değişime Hazırlık

JEL: D23, M10, M19

$\begin{array}{ll}\text { Geliş } & : 10 \text { Mayıs } 2018 \\ \text { Düzeltme } & : 08 \text { Haziran } 2018 \\ \text { Kabul } & : 12 \text { Haziran } 2018 \\ \text { Tür } & : \text { Araştırma }\end{array}$

Keywords: Leadership, Change, Readiness for Change

JEL: D23, M10, M19

$\begin{array}{ll}\text { Received } & : 10 \text { May } 2018 \\ \text { Revised } & : 08 \text { June } 2018 \\ \text { Accepted } & : \text { 12 June } 2018 \\ \text { Type } & \text { : Research }\end{array}$

a PhD., Gebze Technical University, Faculty of Business Administration, Kocaeli, Turkiye, eergun@gtu.edu.tr (ORCID ID: 0000-00029168-7340)

b Gebze Technical University, Faculty of Business Administration, Kocaeli, Turkiye, korayyalcinkaya@yahoo.co.uk (ORCID ID: 00000001-6349-400x) 


\section{Giriş}

Bireyin yaşayabilmesi ve üreyebilmesi için genetik yapısının, yaşadığı çevre koşulları ile uyumlu ve olumlu etkileşim içinde olması gerekmektedir. İnsan biyolojik evriminin yanında kültürel evrime de sahiptir (Akın, Özer ve Gültekin, 2004). Örgütler açısından değişim ise, yeni bir yapı oluşturma, yani mevcut örgütsel yapıyı değiştirerek, değişen koşullara uygun bir yapı yaratmaktır (Çolakoğlu, 2005). İnsanoğlu açısından değişim olgusunun altında, yaşamını devam ettirmek ve huzur içinde yaşamak için yaşam alanlarını tehlike ve endişelerden korumak arzusu ve davranışının yattığını anlaşılmaktadır (Velasquez ve Velazquez, 2002). Çevresel faktörler devamlı değişim içindedir. Çevreyle sürekli etkileşim içerisinde olan örgütler değişime uyum sağlamak için yeni özellik ve yetenekler kazanmak zorundadırlar. İç ve dış çevre kaynaklı farkı intiyaçların karşılanabilmesi, planlı değişimi zorunlu kılmaktadır.

Değişimin en zor parçası, kültürün en temel değer ve inancı olan, zaman içinde telkin edilen kültürün zamansal boyutlarıdır (Kavanagh ve Ashkanasy, 2006). Örgütlerin evrimsel süreçlerinde doğup, büyüyüp, olgunlaşma aşamalarında yaşadığı sorunlar, örgütlerin kültürlerinin oluşmasında belirleyici olmaktadır. Bu sorunlar örgütlerin dış çevre ile uyumları sırasında ortaya çıkan sorunlar ile içsel süreçlerini uyumlu hale getirmeleri sırasında yaşadıkları sorunlardır. Sorunların çözümünde paylaşılan düşünce kalıpları, inanç, hissiyat ve değerler, bunun sonucunda oluşan kabuller örgütün kültürünü oluşturmaktadır. Kültürün oluşmasında örgüt liderinin düşünce boyutu önemlidir (Schein, 2010; Ergün ve Arslantürk, 2016). Örgütlerin, değişebilir özellikler kazanarak bu özelliklerini sürdürülebilir hale getirmeleri ancak güçlü liderler tarafından yönetilmeleriyle mümkün olmaktadır (Saylı, 2008). Bir örgütün kültürünü, hatta bir departmanın kültürünü yeni bir değere veya inanca taşımaya çalışmak, bir liderin karşılaştığı en büyük zorluklardan bir tanesidir. Örgütsel değişim literatüründe, çalışanların değişimin kendilerinde, işlerinde ve çalışma arkadaşlarında yapacağı etki ile ilgili kaygılara sahip olduğu vurgulanmaktadır. Çalışanlarda değişimin oluşturduğu negatif algının bilinmemesi, değişim uygulamasını yönetmeyi zorlaştırır (Rafferty ve Griffin, 2006). Çalışanlarda oluşan değişim algısının liderlik davranışından etkilenebileceği değerlendirildiğinde, lider ve yöneticiler değişim süreci boyunca değişimin ilerlemesi ve karşılaşılan problemlerin çözülmesi konusunda dinamik rol üstlenerek çalışanların değişim algısına etki ederler (Boga ve Ensari, 2009).

Değişim, pozitif sonuçlarının yanı sıra negatif sonuçları da beraberinde getiren karmaşık bir süreçtir. Hızlı teknolojik gelişmelerin arka planı, artan bilgi, işgücü ve kabul görmüş iş pratiklerindeki değişimlere karşın, değişim örgütsel yaşamın kopmaz bir parçası haline gelmektedir. Bununla birlikte birçok organizasyon değişim ihtiyacını takdir ederken, değişim programlarının \%70'i kadar büyük bir kısmı hedeflenen sonuçlara ulaşamamaktadır (Barnard ve Stoll, 2010). Özellikle şirket satın alma birleşmelerde güçlü kültüre sahip örgütlerde değişime direnç yüksek olmaktadır. Şirket evliliklerinde kültürel olarak değişim yaşanacağı ve bu değişime nasıl ayak uydurulabileceğinin önemi büyüktür (Özmutaf, 2007). Örgütsel değişim sürecini inceleyen yazarlardan değişim süreçlerinin başarılı olabilmesine ilişkin yaptıkları araştırmalarda iki önemli konunun ön planı çıktığı görülmektedir. Birincisi değişimin planlı ve sistemli bir süreç olduğu iken, ikincisi çalışanların değişimin gerekliliğine inanarak sürece gönüllü katkı vermeleridir (Kavanagh ve Ashkanasy, 2006).

Değişimin seçimden daha çok bir gereklilik olduğu durumlarda, örgütlerin değişime açık olmaları önemlilik kazanmaktadır. Gelecek, değişim açısından genellikle belirsiz olduğundan, genel olarak insanlar bunu yapmak için zorlayıcı nedenler olmadıkça değişmeye motive değildir. Sonuç olarak, değişim projelerini etkili bir şekilde yönetmek ve planlamakla ilgili önemli bir konu, değişimi destekleyen bir temel oluşturmaktır (Bouckenooghe, Devos ve Broeck, 2009). Değişime hazırlık konusu, değişimi desteklemek ve harekete geçirmek için yalnızca gönüllü olmaktan öte, değişime karşı olumlu duygular ve inançlar içermektedir (Kondakçı, Zayim ve Çalışkan, 2013). Bouckenooghe vd. (2009) tarafından değişime hazırlığı oluşturan üç unsur tanımlanmıştır. Bunlar; insanların karşılaştıkları değişim hakkında nasıl hissettiklerini ifade eden "duygusal hazırlık" (emotional readiness), insanların değişimin sonuçları hakkında sahip oldukları inanç ve düşünceleri içeren "bilişsel hazırlık" (cognitive readiness) ve organizasyon üyelerinin çabaları, isteklilikleri ve enerjilerini ifade eden "davranışsal hazırlık" (intentional readiness) unsurlarıdır (Kirrane, Lennon, O'Connor ve $\mathrm{Fu}, 2017)$. 
Bu çalışma kapsamında şirket birleşme ve satın alma süreci gibi köklü değişimlere uğramış firmalardaki farklı liderlik davranışlarının çalışanların değişime karşı tutumlarını, değişime hazır olma davranışlarını nasıl etki etkilediği araştırılmaktadır. Bu amaç kapsamında ikinci bölümde kavramsal çerçeve ele alınacaktır. Sonrasında araştırmanın uygulamasına yönelik analizler ve çalışmanın değerlemeler yapılacaktır.

\section{Kavramsal Çerçeve}

\subsection{Liderlik ve Liderlik Yaklaşımları}

Lider, bireyleri ortak hedeflere yönelten ve bu hedefleri benimseten, bireyler arası iletişimi sağlayarak, sinerji yaratan kişi olarak tanımlanmaktadır (Ergün, 2018). Yöneticilerin liderlik yeteneklerini geliştirmeye ve performansı yüksek ekipler oluşturmaya ihtiyacı vardır. Günümüz örgütleri başarılı olmak için, yöneticiden çok lidere intiyaç duymaktadır. Çünkü değişimi ve dönüşümü sıradan bir yönetici gerçekleştiremez. Yönetici ile lider arasında önemli farklar bulunmaktadır (Tunçer, 2011). İşletme için hem liderler hem de yöneticiler gereklidir. Bununla beraber yöneticiler insanları etkileme gücünü formal yollarla elde ederken, liderlik sosyal etkileme süreciyle oluşur. Yönetici belirlenmiş prosedür ve tekniklerle iş ve faaliyetlerin gerçekleştirilmesini sağlarken, liderler değişim ile işletmeye yeni bir vizyon vermekle ilgilenirler. Yöneticiler gücünü bulunduğu makamdan alırken, liderler gücünü kişisel özelliklerinden ve kişisel ilişkilerinden alır. Yöneticiler genellikle örgütün üst kademelerinde bulunurken, liderler örgütün her düzeyinde bulunabilir. Yöneticiler başarı için, sistemle uyumlu olarak kuralları uygulayarak işleri doğru yapmaya çalışılar ve denetime güvenirler. Liderler ise başarı için insana güvenip, doğru işleri yaparak, kendi tasarlamış olduğu hedeflerle örgütü daha iyi duruma götürürler. Yöneticiler belirsizliklerden çekinir ve kısa vadeli hedeflere yönelirler. Liderler ise değişiklik yapma, risk alma eğilimlidirler ve uzun vadeli hayalleri vardır. Liderler; değerler ve bağlılık gibi konuları ön planda tutarlar (Ergün ve Çelik, 2015).

Liderlik süreci; liderin kendisi, izleyiciler ve koşullar arasındaki ilişkilerden oluşan karmaşık bir süreçtir. Evrensel ve durumsal liderlik teorileri, liderlerin başkalarını nasıl ve hangi mekanizmalarla etkilediğini açıklanmaya çalışmıştır. Her teori, liderlik sürecinin farklı yönlerini ele alarak farklı değişkenlere ağılık vermiştir. Değişen koşullarla beraber, değişen liderlik uygulamaları, farklı yaklaşımların doğmasına sebep olmuştur (Yukl, 2012). Örgüt liderliği özünde, bireyi ve grubu etkileyerek hedefleri gerçekleştirme çabalarını destekler. Liderler performansı belirleyen süreçler ile çalışanların performansını artırabilirler. Liderlik araştırmalarının en önemli amaçlarından biri, liderin bir takımın, bir çalışma biriminin veya organizasyonun performansını etkilediği davranışları belirlemek olmuştur. Liderlikle ilgili yaklaşımları, özellikler yaklaşımı, davranışsal yaklaşım, durumsal yaklaşım ve yeni yaklaşımlar olmak üzere dört grupta toplamak mümkündür.

Bir kişinin lider olarak kabul görmesini ve o grubu yönetmesini kişinin fiziksel ve kişilik özellikleri ile ilişkili olduğunu savunan "Özellikler Teorisi", liderlik konusundaki ilk yaklaşımlardan biridir (Yukl, 2010). Liderliği belirlediği varsayılan fiziksel ve kişilik özelliklerinin hepsinin bir kişide olmasının mümkün olmaması, bunların kolay ölçülememesi ve liderden daha fazla bu özelliklere sahip kişilerin lider olarak ortaya çıkmaması konularında teori eleştirilmiştir (Bakan ve Büyükbeşe, 2010). Liderlerin liderlik vasfı üstlenmelerinde, fiziksel ve kişilik özelliklerinden daha çok davranışlarının etkili olduğu düşüncesine yoğunlaşan "Davranışsal Yaklaşımlar" çerçevesinde birçok araştırma gerçekleştirilmiştir. Ohio State ve Michigan Üniversitelerindeki liderlik araştırmaları ile Blake ve Mouton'un yönetim tarzı modeli (Managerial Grid) gibi çalışmalar, liderlerin iş odaklı olma ve kişi odaklı olma eğilimlerini ve bu eğilimlerin muhtemel etkilerinin açıklanmasını sağlamıştır. Ohio State Üniversitesi'nin çalışmalarında; lider ilişki odaklı ise işe devamsızlık ve personel devir hızı azalmakta, görev odaklı ise grup üyelerinin performanslarının artmakta olduğu gibi bulgular elde edilmiştir (Luthans, 2010).

Davranışsal kuram, liderlik sürecinin anlaşılmasına önemli katkılarda bulunmuştur. Durumsal yaklaşım, liderin etkinliğinin, liderlik biçimini karşılaştığı duruma uygun olacak şekilde değiştirebilmesine bağı olduğunu savunmaktadır. Durumsal liderlik teorileri, takipçilerin yetenekleri, beklentileri, örgütün kültürü, lider ile beraber yaşanan daha önceki tecrübeler, amaçların niteliği gibi koşullara uygun liderlik davranışlarının, liderin etkinliğini belirleyeceğini savunmuştur. Durumsallık yaklaşımlarının temel görüşü, 
organizasyonların yapılanmasında ve yönetiminde tek bir en iyi yolun olmamasıdır. Organizasyon tasarımının mevcut çevre koşullarına uygun olması gerekir (Luthans, 2010).

Her dönemde, zamana ve koşullara göre, kültürel farklılıklardan etkilenen değişik türde liderlerin ortaya çıktığı, ancak değişenin sadece liderlik kavramının kapsamı ve algılanma biçimi olduğu görülmektedir. Çünkü toplumlar sürekli bir değişim ve gelişim içindedirler. Çevre koşullarıyla beraber insanlar da değiştiği için daha önce geçerli olan liderlik tarzları ve davranışları geçerliliğini kaybetmekte yeni lider tipleri ortaya çıkmaktadır. Günümüz küresel rekabet ortamında, post-modern yeni liderlik yaklaşımları geliştirilmiştir. Bu yaklaşımlar karizmatik, vizyon sahibi ve dönüşümcü liderlik olarak üç ana yaklaşımdan oluşmaktadır. Bu yaklaşımların ortaya çıkmasında değişen koşulların ve liderlik sürecine bakış açısındaki değişikliğin de katkısı olmuştur. Karizmatik liderler kendi dünya görüşlerini izleyicilerine aktarmakla yetinmektedir. Oysaki günümüzde sadece liderin dünya görüşü ile kısıtlı kalmayıp, örgütün ihtiyaç duyduğu motivasyonu vererek, izleyenleri dönüştürebilen hatta bu süreçte liderin kendisinin de dönüştüğü bir anlayışa dayanan dönüşümcü liderlik yaklaşımına ihtiyacı doğmuştur. Bu gelişmeler doğrultusunda liderlik teorilerinde üzerinde daha önce fazla durulmayan gelecek, yenilik, değişim ve reform kavramları liderlik sürecine girmiştir. Liderlikte geleceğe, yeniliğe, değişime ve reforma dönük olan liderlik dönüşümcü liderlik şeklinde adlandırılmıştır. Bu gruba giren liderlik davranışları da değişim odaklı liderlik davranışları olarak isimlendirilmiştir (Taş ve Önder, 2010).

Dönüşümcü lider, ihtiyaçları ve değer yargılarını değiştirerek, izleyenleri değişimi başarabilecek performansa ulaştıran kişidir. Dönüşümcü lider vizyon sahibidir ve bu vizyon çalışanların heyecanını körükler. Dönüşümcü liderler, karizma, geleceği görmek, empati yapabilmek gibi özelliklere sahiptir. İşlerin devamlılığına önem veren işlemsel (transactional), liderler geçmişle bugünü bağdaştırarak, geçmişteki olumlu ve yararlı gelenekleri sürdürmek, bunları gelecekteki nesillere bırakmak açısından katkıda bulunurken, dönüşümcü liderler, bugün ile geleceği bağdaştırmaya çalışıp, yenilikçi ve yaratıcı etkinlikleri özendirerek, grup ve örgüt başarısını artırıcı bir rol oynarlar (Bakan ve Büyükbeşe, 2010).

\subsubsection{Liderlik Davranışları}

Yönetim literatüründe 1950'lerde liderlik davranışları; görev odaklı ve insan ilişkileri odaklı davranışlar olarak iki kategori ile sınıflandırılmaya çalışılıyordu. Bu yaklaşım bireyleri veya takımı etkilemek üzerine geliştirilen lider davranışlarını temsil etmekteydi. Ancak, liderin doğrudan değişimi teşvik eden ve kolaylaştıran davranışları bu kategoriler altında sınıflandırılmamaktaydı. Değişim odaklı davranışa 1980'lerde, bazı karizmatik ve dönüşümcü liderlik teorilerinde değinilmektedir. Ancak yine de ayrı bir boyut veya kategori olarak açıkça tanınmıyordu (Yukl, 2010). 1990'larda üçüncü bir kategori olarak değişim odaklı liderlik davranışı yönetim literatüründe yeni bir liderlik davranışları sınıflandırması olarak çalışılmaya başlanmıştır (Ekvall ve Arvonen, 1991; Yukl, 1999).

Liderlik davranışlarının algılanmasında, hiyerarşik basamakların önemi kadar, hiyerarşik kademelere göre lider davranışlarının algılanma farklılıkları da önemlidir. Literatürdeki araştırmalarda değişim odaklı liderlik anlayışının, üst yönetim kademelerinde daha yüksek düzeyde algılandığı belirlenmiştir. Bununla beraber işlevsel görevlere sahip alt kademe yöneticilerin ise düşük düzeyde değişim odaklı davranış özelliği göstermesi doğaldır (Avolio ve Bass, 1988). Üst kademe yöneticiler fonksiyonel liderlik davranışlarının yeterliliği konusunda orta kademe yöneticilerden daha başarılı olmaktadır. Günümüz rekabet koşullarında tüm yönetsel kademelerdeki yöneticilerin işlevleri artmıştır. Daha esnek yapıya kavuşan örgütlerde her yönetsel seviyede yöneticilerin karar alması gerekmektedir. Bu durum alt ve orta kademe yöneticilerin işlevlerini artırmıştır. Liderlik yeteneklerinin yönetsel kademeye göre farklılık gösterdiği tespit edilmiştir. Bilişsel yetenekler tüm örgütsel kademelerde gerekli iken, stratejik yetenekler daha çok örgütün üst kademe yöneticileri için gerekli ve önemlidir. Michigan Üniversitesi liderlik çalışmaları bulgularına göre işe ve çalışana odaklı liderlik tarzı ile işin türü arasında bir ilgi vardır. İşin yapısal olarak tam belirlenmediği değişimlerin olduğu durumlarda, işe dönük liderlerin daha başarılı oldukları, buna karşın işlerin ve ilişkilerin belirli olduğu iş yerlerinde ise kişiye yönelik liderlik tarzını benimsemiş liderlerin daha başarılı oldukları görülmüştür (Yukl, 2010). 
Örgütün ve insanların değişime ve yeniliklere verdiği tepki, önemli ölçüde liderin davranışlarına göre şekillenmektedir. Kültürel değişim liderin kendine özgü benzersiz karizmatik müdahalelerine bağlıdır. Örgüt liderleri örgüt kültürü üzerinde önemli bir etki kaynağıdır. Örgütsel iklim ve kültür, liderlerin üzerinde önemli kontrol ve nüfuz sahibi oldukları toplumsal ve sosyal yapıları temsil etmektedir (Kavanagh ve Ashkanasy, 2006). Bununla birlikte, liderlerin etkisi başkalarının onları nasıl gördüklerine bağlıdır. Çalışanlar liderlerine inandıklarında, alınan kararları kabul edip, liderin eylemlerine destek olurlar. Yönetim; planlama, örgütleme ve kontrol süreçleriyle ilgilidir, liderlik ise insanları değişime motive etme sürecidir. Liderler çalışma ortamının ve örgüt kültürünün doğasını etkileyerek, çalışanların değişime karşı tutumlarını ve motivasyonlarını etkiler (Schein, 2010; Kavanagh ve Ashkanasy, 2006).

Dönüşümcü liderlik ve örgütsel değişim teorileri, değişimin liderlerin güçlü, inandırıcı kişisel özellikleri ve kültürel yapıyı değiştirmek için tasarladıkları eylemler ile oluşturdukları vizyonla gerçekleştiğini vurgular. Liderlerin vizyon yaratarak değişikliği teşvik etmeleri ve önemli bir değişimle karşı karşıya kaldıklarında başkalarını ortak amaçlar için mücadele etmek için harekete geçirmeleri beklenmektedir. Liderler, değişim ajanları olarak başarılı bir şekilde hareket etme ve diğerlerini takip etmeleri için motive etme konusunda başarılı olmak zorundadırlar (Avolio ve Bass, 2001; Kavanagh ve Ashkanasy, 2006).

Liderin sergilediği davranışlar şu şekilde gruplandırılmaktadır (Yukl, 2010):

- ilişki Odakı Liderlik; Liderin izleyenlerine gösterdiği güven, saygı, değer ve iyi ilişkiler, ilişki yönelimli davranış olarak tanımlanır. iliş̧i odaklı liderler, izleyenleri ile aralarındaki iletişim yollarını geliştirerek, görev ve sorumlulukları delege eder, astlarını güçlendirir ve onlarla iyi ilişkiler geliştirmeyi hedeflerler. Çalışan odaklı liderler, örgütsel amaçlara ulaşmak için kullanılan araçlar üzerine yoğunlaşır ve astlarına tam olarak güvenerek denetim gereksinimini en aza düşürme eğiliminde olurlar (Ergün ve Çelik, 2015). Karşlıklı güven, arkadaşlık ve duygusal destek sağlayan davranışlarla izleyenlerine yaklaşarak, örgüt üyelerinin sosyal ve duygusal ihtiyaçlarının tatmin edilmesini amaçlarlar. Liderin çalışanlarına karşı kaliteli iletişim sergilemesi çalışanlarla saygılı, etkin ve iyi bir ilişki içerisinde olmasını sağlar. Çünkü kaliteli iletişim ve etkileşim çalışanların kendilerini değerli hissetmelerine de neden olmaktadır (Tekin, 2018). İlişki odaklı liderler çoğunlukla astları için iyilik yapma, onlara birtakım şeyleri açıklama ve onların refahını temin etme gibi faaliyetlerle meşguldürler. Görevin yerine getirilmesi ikinci planda yer almaktadır ve bu nedenle üretkenliği ihmal etmeleri mümkündür (Özdevecioğlu ve Kanıgür, 2009).

- Görev odakı liderlik; Görev davranışı, izleyenlerin görevlerini tanımlamak, bu görev tanımlarının gerektirdiği aksiyonların nasıl, ne zaman ve nerede yapılacağı açık bir şekilde tanımlanması yönelik çabalardır. Görev odaklı liderler ödüllendirme ve ceza güçlerini kullanarak performansı yakından izler ve denetler. Görev atama, işin teslim süresi, işin standartlara uygun yapılıp yapılmadığı, belirlenmiş performansların sürdürülmesi önemli konulardır (Yukl, 2010). Disiplin düzeyinin yüksek olduğu ve çıktıların daha fazla önemsendiği durumlarda görev odaklı liderlik davranışı önem kazanmaktadır. Görevin karmaşık ve belirsiz olduğu durumlarda, takipçilerin işi bilen ve konuya hâkim, görev odaklı davranış sergileyen bir lider beklentisi artacaktır. Bununla beraber yapılacak iş, isteklendirme ve teşvik gerektiriyorsa, görev odaklı davranış takipçileri harekete geçirmeye yetmeyebilecektir ve hatta iş performansına olumsuz etki yapabilecektir. Görev odaklı lider, ilişki odaklı lidere göre çok daha ayrıntılı çalışma planları ortaya koyar. Görev odaklı lider çalışanlarda başarılı sonuçların elde edileceğine dair algıyı artıırken, ilişki odaklı liderler çalışanları duygusal olarak liderlerinin isteklerine daha gönüllü olmalarını sağlamaktadırlar (Soydemir vd., 2014).

- Değişim Odaklı (Dönüşümcü) Liderlik; 1978 yılından sonra yapılan araştırmalarda, liderlik davranışları, geleneklere bağlı liderlik ile geleceğe/değişime dönük liderlik davranışı olarak ikiye ayrılmıştır. Geleneklere bağıı liderler çalışanlarını güdülemede, ödüllendirme, para ve statü gücünü kullanılırken; dönüşümcü liderler, ilham ve vizyona yöneltme biçiminde çalışanları etkileyerek başarıyı elde ederler (Bakan ve Büyükbeşe, 2010). Dönüşümcü liderler, çalışanlara vizyon kazandırıp, değişimin gerekliliğine inandırıp, izleyicilerin arzu ve gayretlerini artırarak, 
özgün fikir ve çalışmaların ortaya çıkmasını sağlarlar. Geleneklere bağlı liderler ise, yararlı gelenekleri gelecek nesillere aktarma çabası içerisinde, çalışanların alışılagelmiş faaliyetlerini daha etkin hale getirerek veya iyileştirerek iş yaptırma yolunu seçerler (Cömert, 2004). Değişim odaklı liderlik, geleneklere bağlı liderlerden farklı olarak, günümüzün rekabetçi, yenilikçi şartlarına daha uygun liderlik davranışı olarak karşımıza çıkar.

Değişim odaklı liderler, çalışanları denetlemekten çok görevi başarmaları için yardım eden, geliştiren, duygusal olarak bağılı̆̆ı artırıp; görevin amacının içselleştirilmesini önemseyen liderlerdir. Aynı zamanda izleyenlerin kişisel gelişimlerine önem veren ve empati yetenekleri gelişmiş liderlerdir. Lider ve izleyici arasında çok yoğun bir etkileşim vardır. Birbirlerinin üst düzey gereksinimlerini karşılayarak güdülenirler. Lider astların bireysel farkılıklarını, gereksinmelerini ve yeteneklerini nasıl belirleyeceklerini de öğretir. Bu sayede zor hedeflere ulaşmayı başarırlar. Dönüşümcü lider izleyicinin eğilimini, ihtiyacını, isteğini fark eder ve bu ihtiyacı izleyiciyi güdülemek için kullanır (Cömert, 2004). Liderlik bireylerin özellikle değişim dönemlerinde dahil edilmek, desteklenmek, güçlendirilmek istedikleri sosyal bir etki sürecidir. Değişim sürecinde yer alan bireyler için ortaya çıkan sonuçlar olumlu olduğunda liderler çalışanlar tarafından kabul görecektir (Kavanagh ve Ashkanasy, 2006).

\section{2. Çalışanların Değişim Kapasitesi}

Örgütler sürekli değişim içerisinde olan bir çevre içerisinde faaliyet gösterirler. Bu nedenle değişim örgütlerin kaçınılmaz süreçleri ve stratejileri halini almıştır. Değişim süreçleri algıya dayalı, yazıı ve resmi olmayan bir sözleşmedir. Bu sebeple, iş̧̧iler ve işverenler değişim süreçlerindeki yükümlülüklerine farklı açılardan bakabilir ve her bir taraf yükümlülüklerini ne derecede yerine getirdikleriyle ilgili farklı görüşlere sahip olabilirler. Çalışanlar genellikle psikolojik sözleşmelerinde iş güvenliği ya da gelişim fırsatları gibi durumlarla ilgili olumsuz değişimler olacağından endişelenirler (Barnard ve Stoll, 2010). İ̧̧ ortamı, insanlar, resmi ve resmi olmayan sistemlerden oluşan sosyal sistemler gibi örgütler de doğalarında değişime karşı dirençlidir ve değişim girişimlerinin etkisini nötrleştirmek için tasarlanmışlardır (Kavanagh ve Ashkanasy, 2006). Çalışanların, organizasyonları için çok önemli bir değer oldukları düşünüldüğünde, mevcut potansiyellerini tam olarak ortaya koymaları, organizasyona bağlılıklarını artırarak liderleri için rol ötesi davranışlarda bulunmaları, fiziksel çabaları yanında duygusal destekleri de olmalıdır (Alparslan ve Oktar, 2015).

Değişimle ilgili yapılan çalışmalarda, örgütsel değişimlerde bireyleri değişime hazırlama faaliyetlerinin genelde göz ardı edildiği görülmekte, değişimlerde bireysel hazırlıktan daha çok örgütsel düzeyde hazırlık yapılmaktadır. Rafferty vd. (2013) örgütteki değişimlere öncelikle bireysel düzeyde hazırlıkla başlanması ile değişimin daha başarılı olacağını belirtmektedir. Örgütsel değişimin başarısı için temel unsur, değişimin çalışanlar tarafından kabul edilmesidir. Değişimlerin daha verimli ve istenilen şekilde kabul edilmesi değişime hazır olma durumuyla yakından ilgilidir. Değişime hazırlık, "değişiklik çabasına karşı gelişen destek ya da direnç davranışının bilişsel öncüsü" olarak tanımlanırken değişime hazır olma, "çalışanların değişimi gerekli görmesi ve örgütünün bu değişimi başarılya gerçekleştirebileceğine olan inanç, tutum ve niyetinin ölçüsü" olarak tanımlanmıştır (Kayasandık, 2017). Çalışanlar kendilerini örgütleriyle ne kadar bağdaştırır ve örgütlerine ne kadar fazla bağlılık gösterirlerse, örgütsel değişimi kabul etmeye olan istekleri o kadar fazla olmaktadır (Vakola ve Nikolaou, 2005). Kültür değişiminde doğru yaklaşım seçmenin anahtarı örgütlerin işleyiş şekillerini dikkate almaktır. Liderler, uygun değişim yönetimlerini ve yaklaşımlarını seçmekte ve planlanmasında kritik rol oynamaktadırlar. Liderler, katılımcıların karar alma sürecinin bir parçası olduklarını, bu süreçte kendilerine danışıldığını ve sürecin içerisinde yer aldıklarını hissettirecek davranış ve tutum içerisinde olmalıdırlar (Kavanagh ve Ashkanasy, 2006).

Elizur ve Guttman'a (1976) göre değişime karşı geliştirilen tutum, genelde bireyin değişime ilişkin bilişsel (zihinsel) düşünceleri, değişime gösterdiği duygusal reaksiyonları ve değişime karşı davranışsal eğilimlerinden oluşur. Bu nedenle araştırmacılar çeşitli çalışanların örgütsel değişime karşı verdikleri tepkileri güçlü pozitif tutumlardan (Örneğin; Bu değişim örgütün başarılı olması için şarttır) güçlü negatif tutumlara (Örneğin; Bu değişim şirketi mahvedebilir) kadar sıralamışlardır. Bu nedenle değişim, heyecan ve mutluluk veya öfke ve korkuyla karşılanabilirken, çalışanların tepkileri değişimi destekleyen pozitif niyetlerden 
değişime karşı duran negatif niyetlere kadar çeşitlilik gösterebilir. Birçok çalışma, örgütsel değişim için gösterilen çabaların bireyler için çok stresli bir deneyim olabileceğini öne sürmektedir. Değişime yönelik duygular ve tepkiler oldukça yoğun olabilir. Bu tepkiler, bireylerin ölüm ve hüzün gibi travmatik değişime verildiği tepkilerle karşılaştırılmıştır. Daha açık ifade etmek gerekirse, bir bireyin değişim sürecinde denge, inkâr, öfke, pazarlık, kaos, depresyon, istifa, açıklık, hazır olma ve yeniden ortaya çıkma gibi birçok duygusal durumu deneyimlediğini ortaya koymuşlardır. Değişimden kaynaklanan direnç seviyesini etkileyen kişilik belirleyicilerinin yanı sıra bağlam değişkenlerinin de önemli bir role sahip oldukları belirtilmiştir (Oreg, 2003). Yönetimdeki güvenin, duygusal, bilişsel ve davranışsal direnç üzerinde oldukça güçlü bir etkisi olduğu tespit edilmiştir. Bu da değişim sürecinde iyi yönetim becerilerinin önemini vurgulamaktadır (Barnard ve Stoll, 2010).

Değişime hazırlık, "bir değişim çabasına karşı direnişin veya destek için davranışların bilişsel öncülü" olarak tanımlanmaktadır (Armenakis, Harris ve Mossholder, 1993:681). Bununla birlikte değişime hazırlık, çalışanların değişim inisiyatiflerine yönelik desteklerinde temel oluşturan en önemli faktörlerden biridir (Armenakis, Harris ve Feild, 2000). Değişime karşı tutum, değişime açıklık, değişimi problem olarak görme, değişimi risk olarak görme, değişime duygusal, davranışsal ve bilişsel olarak hazır olmak gibi değişkenler bağlamında ele alınmıştır:

- Değişime Açıklık ve Değişimi Problem Olarak Görme; Değişime açıklık, örgüt üyelerinin, değişim sürecini anlamaları ve değişimi içselleştirerek, davranışları ile beklentilerinin uyum içinde olmasıdır. Değişim sürecinin başarısı, örgüt çalışanlarının değişime açıklığı ile doğru orantılıdır. Çalışanların değişime açıklık ve değişimi problem olarak görme konusundaki tutumlarının yeterince anlaşılamaması ve tutumların olumlu tutumlara dönüştürülememesi, değişim süreçlerinde birbirini besleyen olumsuz süreçlere yol açmaktadır. Çalışanlar değişim sürecinde belirtilen yeniliklerle ilgili uygun davranışları göstermedikleri sürece değişim meydana gelmeyecektir (Demirtaş, 2012). Örgütsel değişimin sebep olabileceği ekstra iş yükü, çalışanın değişim sürecini problem olarak görmesine sebep olabilir. Örneğin değişim sırasında ya da değişimden sonra eski ve yeni sistem bir süre birlikte sürdürülecek ve bu da ekstra iş yüküne sebebiyet verecekse, çalışanlar değişime karşı negatif tutumlar sergileyebilir ve bunun sonucunda değişime katkıda bulunmak istemeyebilirler. İş yükündeki artış değişimle ilişkilendirilmekle kalmayıp, değişimin kendisinin kötü ve problem kaynağı gibi gösterebilirler; bunun sonucunda da destek olmayan tutumlar ortaya çıkabilir.

- Değişimi Risk Olarak Görme; Değişim süreçleriyle beraber oluşan belirsizlik ortamları, kişilerin risk alarak çalışmasını gerektirir. Belirsizlik sebebiyle ortaya çıkan bilgi yetersizliği, karar alma konusunda tereddütlere sebep olur. Alınamayan kararlar işletmenin fırsatları değerlendirememesine ve rekabet de geri düşmesine sebep olur. Dolayısıyla çalışanlar belirsizlik ortamlarında risk alarak karar vermek zorundalardır. Çalışanı risk almaya iten güdünün kişinin girişimci ve yenilikçi bir yapıya sahip olması olduğu değerlendirilmektedir. Kişinin kendisinden beklenen durumları yönetmesini sağlayacak yeteneklere olan inancı (öz yeterlilik) yüksek olan bireyler, yenilikçi davranabilmekte ve risk alabilmektedirler. Kişilerin problemlerle baş edebileceklerine inanmaları, değişimi başlatma ve belirsizlik altında risk alarak doğru eylemlerde bulunmalarına olumlu şekilde etki edeceği varsayılmaktadır. Kişilerin yeterlilik beklentilerine ilişkin algıları, eyleme geçme ve sorunlarla mücadele azimlerini etkiler. Liderler bireylerin kendilerine zor ve gerçekçi hedefler seçmelerini ve bu hedeflere daha fazla bağılık göstermelerini sağlamak suretiyle, onların bireysel performanslarını olumlu yönde etkileyebilirler (Basım, Korkmazyürek ve Tokat, 2008).

- Değişime Duygusal Olarak Hazır Olma; Değişim çabası sadece örgütlerin değil aynı zamanda bireylerin de üzerinde baskı yaratmaktadır. Örgütsel değişim, işlerin yapılma biçimini zorlaştıran ve karşı çıkan bir yapıya sahiptir. Bunun sonucunda bireyler belirsizlikler yaşar. Bu da bireylerde yeni durumla başa çıkamama korkusunu uyandırır (Vakola ve Nikolaou, 2005). Çalışanlar, kültürel değişim ortaya çıktığında, performans ve sadakat ölçeklerinin aniden değiştiğinin farkına varırlar. Eski kurumsal değerler ve örgütsel yaşam tarzlarına yönelik bu tehdit, örgüt üyelerini savunmasız 
durumda bırakır. Bu savunmasızlık kurum içindeki düşük güven seviyelerinden ve kültürel şoktan kaynaklanmaktadır. Çalışanların tepkilerinin dört aşamadan geçtiğini ileri sürülmektedir. Bunlar; (1) güvensizlik ve inkâr, (2) öfke ve kızgınlık, (3) öfke ve depresyonla başlayan duygusal pazarlık ve nihayetinde (4) kabullenme. Bu farklı aşamalar kabul edilmez ve ciddi bir şekilde ele alınmazsa, çalışanlar değişime karşı kızgınlık besleyecek, kabul aşamasına gelmekte güçlük çekecek ve değişim sürecindeki hata riskini önemli ölçüde artırılacaktır (Kavanagh ve Ashkanasy, 2006). Kabul, direniş, bağlılık, sinizm, stres ve ilgili kişisel tepkiler, örgütsel değişimin planlanması ve uygulaması çerçevesinde dikkate alınması gereken kriter değişkenleridir. Değişim sinizm ve strese neden olabilir; bu da başarıyı engeller (Vakola ve Nikolaou, 2005). Değişime hazır olma sadece değişimi destekleme ve hayata geçirme gönüllülüğü değil, aynı zamanda değişime karşı bireyde olumlu duygular ve inançların oluşmasını ifade eder. Değişime olan duygusal reaksiyonların gelecekte gerçekleşecek değişimin beklenilen yönde olacağına dair hissedilen mevcut duygulardan kaynaklanmaktadır (Baumgartner ve Strayer, 2008).

- Değişime Bilişsel Olarak Hazır Olma; Çalışanların değişime bilişsel olarak hazır olmaları için öncelikle değişimin gerekliliğine dair inancın kendilerinde oluşması gerekmektedir. Bununla beraber değişimin alternatifinin de ortaya konulmuş olmasını beklerler. Bundan sonraki aşamada örgüt üyelerinde değişim girişimi yürütecek yeterlilik algısının oluşmuş olması gerekmektedir. Bununla beraber örgütü tarafından değişime ilişkin kaynak ve bilgi açısından destekleneceğine inanması gerekmektedir. Birey değişim sonrası işinde ve rolünde yaşayacağı fayda/maliyeti değerlendirmesi yapmaktadır. Eğer birey değişimden fayda sağlayarak çıkacağını düşünmüyorsa bilişsel olarak değişime hazır olma potansiyelinde olumlu bir artış beklenmemelidir (Kavanagh ve Ashkanasy, 2006).

- Değişime Davranışsal Olarak Hazır Olma; Değişimde örgüt liderlerinin tüm bireylerin yeni davranışları uygulayabilmesi ve bu yeni kültürü test edebilmeleri için psikolojik bir güvenlik atmosferi yaratmaları oldukça önemlidir. Bireylerin, yeni inanç ve değerlerin geçerliliğini doğrulamak, bunların kendileri için doğuracağı sonuçlarını incelemek ve kişisel olarak değişim çabasına nasıl katkıda bulunabileceklerini keşfetmek için katılımları esastır. Değişim sürecinin kabul edilme seviyesi, sürecin yönetim şeklinin bir sonucu olarak bireyler için ortaya çıkan sonuçlarla ilgilidir (Kavanagh ve Ashkanasy, 2006).

Teorik açıklamalardan hareketle aşağıdaki hipotezler ve araştırma modeli (Şekil 1) geliştirilmiştir.

Şekil 1. Araştırmanın Modeli

\begin{tabular}{|l|l|l|}
\hline Liderlik Davranışları & Çalışanların Değişim Kapasitesi \\
\hline Görev Odaklı Liderlime Açıklık \\
\hline Dilişki Odaklı Liderlik
\end{tabular}




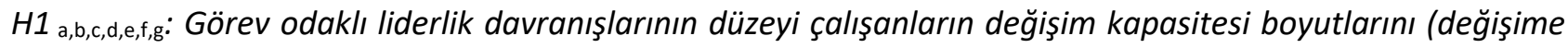
açık olma, değişime direnç gösterme, değişimi problem olarak görme, değiş̧imi risk olarak görme, duygusal hazırık, bilişsel ve davranışsal hazırlık) etkiler.

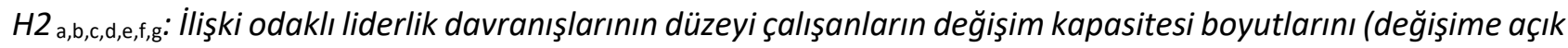
olma, değişime direnç gösterme, değişimi problem olarak görme, değişimi risk olarak görme, duygusal hazırlık, bilişsel ve davranışsal hazırlık) etkiler.

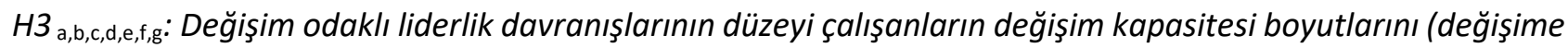
açık olma, değişime direnç gösterme, değişimi problem olarak görme, değişimi risk olarak görme, duygusal hazırlık, bilişsel ve davranışsal hazırlık) etkiler.

\section{Yöntem}

Çalışmanın amacı, liderlik davranışları ile çalışanların değişim kapasitesi arasındaki ilişkiyi incelemektir. Bu amaçla liderlik davranışları boyutları (Görev Odaklı Liderlik, illişki Odaklı Liderlik ve Değişim Odaklı Liderlik) ile çalışanların değişim kapasitesi boyutları (Değişime açıklık, Değişime Direnç, Değişimi problem olarak görmek, Değişimi risk olarak görmek, Değişime duygusal olarak hazır olmak ve Değişime davranışsal-bilişsel olarak hazır olmak) arasındaki ilişkisel bağ incelenmektedir.

Bu araştırmada, birincil veri toplama tekniği olarak anket uygulaması yapılmıştır. Bu bağlamda veriler, ilgili örnekleme dâhil edilen kişilerden yazılı anket formu kullanılarak elde edilmiştir. Anket formundaki değişkenler; gruplar halinde sorulmuş, değişkenler arasındaki farklılıkları göstermek ve birbiriyle karıştırılmaması için açıklayıcı cümlelerle ifade edilmiştir. Veri toplamak için kullanılan anket formlarının cevaplandırımasında 5'li Likert ölçeği kullanılmıştır (1-Kesinlikle katılmıyorum, 5- Kesinlikle katılıyorum). Ankette, görev odaklı liderlik davranışını ölçmek için 10 adet ifade, ilişki odaklı liderlik davranışını ölçmek için 10 adet ifade ve değişim odaklı liderlik davranışını ölçmek için 13 adet soru ifadesi kullanılmıştır. Liderlik davranışları ölçeğinde kullanılan ifadeler Yukl (2010), ölçeğinden uyarlanmıştır. Ankette liderlik boyutlarıyla ilgili 33 adet ifade sorulmuştur. Ankette çalışanların değişim kapasitesini ölçmek için (değişime açık olma, değişimi problem olarak görme, değişimi riskli görme) 14 adet ifade, değişime hazır olma potansiyellerini ölçmek için (değişime duygusal, davranışsal ve bilişsel hazır olmak) 13 adet ifade kullanılmıştır (Bouckenooghe vd., 2009; Dunham vd., 1989) çalışmalarından derlenmiştir.

Araştırma evrenini, Kocaeli bölgesinde bulunan satın alma, birleşme, yaşamış firmalar oluşturmaktadır. Bu evren içinden seçilen toplam 17 firmanın çalışanlar araştırmanın örneklemini oluşturmaktadır. Araştırma örneklemini oluşturan tüm firma çalışanlarına anket uygulanması planlanmış; ancak maliyet, zaman gibi kısıtlayıcı nedenlerden dolayı tüm çalışanlara uygulanamamıştır. Bu kapsamda, çalışan sayısı 50 kişi üzerinde olan 17 firmanın değişim süreci öncesini yaşamışolan beyaz ve mavi yaka çalışanlarına anket uygulanmıştır. Ankete 140 çalışan katılmıştır. Veri toplama süreci sonunda elde edilen veriler, SPSS 16 programında tasviri istatistikler, faktör analizi, regresyon analizi, korelasyon analizi gibi çeşitli istatistiki teknikler aracılığı ile değerlendirilmiştir.

Araştırmada elde edilen veri ve bilgilerin analizinde, SPSS programının 16.0 versiyonu kullanılmıştır. Araştırmada kullanılan analizler; faktör analizi, korelasyon analizi ve araştırma hipotezlerinin test edilmesi için yapılan regresyon analizlerinden oluşmaktadır. Araştırmadaki bulgular, $p<0,01$ ve $p<0,05$ anlamlılık düzeylerinde sınanmıştır.

Araştırma bulgularına göre (Tablo 1 ) anket çalışmasına katılan çalışanların \%79'u erkek, \%21'i kadındır. Eğitim durumları açısından katılımcıların \%65'i yüksek öğretim, \%35'i ilköğretim ve lise mezuniyet düzeyindedir. Katılımcıların yaş ortalaması 38, ortalama kıdemi 9,8 yıldır. 
Liderlik Davranışlarının Çalışanların Değişim Kapasitesine Etkileri: Bir Araştırma Çalışması

Tablo 1. Araştırmaya Katılan Çalışanların Demografik Özellikleri

\begin{tabular}{|c|c|c|c|}
\hline & & Frekans & Yüzde (\%) \\
\hline \multirow{3}{*}{ Cinsiyet } & Kadın & 29 & 21 \\
\hline & Erkek & 111 & 79 \\
\hline & Toplam & 140 & 100 \\
\hline \multirow{6}{*}{ Yaş } & 25 yaş altı & 11 & 8 \\
\hline & $25-29$ arası & 13 & 9,3 \\
\hline & 30-39 arası & 54 & 38,4 \\
\hline & 40-49 arası & 49 & 35 \\
\hline & 50 ve üstü & 13 & 9,3 \\
\hline & Toplam & 140 & 100 \\
\hline \multirow{6}{*}{ Eğitim } & İlk-Ortaöğretim & 16 & 11,4 \\
\hline & Lise & 33 & 23,6 \\
\hline & Yüksekokul & 28 & 20,0 \\
\hline & Lisans & 37 & 26,4 \\
\hline & Lisansüstü & 26 & 18,6 \\
\hline & Toplam & 140 & 100 \\
\hline \multirow{6}{*}{ Çalışma Süresi } & 5 yıl altı & 43 & 30,9 \\
\hline & $5-9$ arası & 38 & 27,3 \\
\hline & $10-14$ arası & 26 & 18,5 \\
\hline & $15-19$ arası & 11 & 7,8 \\
\hline & 20 ve üstü & 22 & 15,5 \\
\hline & Toplam & 140 & 100 \\
\hline
\end{tabular}

\section{1. Ölçüm Geçerliliği ve Güvenilirliği}

Aşağıdaki tablolarda, faktör analizlerinin sonuçları verilmiştir. Faktör analizini uygularken bağımsız değişkenler ile bağımlı değişkenler ayrı ayrı ele alınmıştır. Bağımsız değişken boyutları görev odaklı liderlik, ilişki odaklı liderlik ve değişim odaklı liderlik; bağımlı değişken boyutları değişime açıklık, değişime direnç, değişimi problem olarak görmek, değişimi risk olarak görmek, değişime duygusal olarak hazır olmak ve değişime davranışsal ve bilişsel hazır olmak faktör analizine tabii tutulmuştur.

Bağımsız değişkenler olan liderlik boyutları ile ilgili 24 soru sorulmuş olup, faktör analizi sonucunda beklendiği gibi üç faktöre ayrılmıştır. Bu faktörler; görev odaklı liderlik (6 soru), ilişki odakı liderlik (10 soru), değişim odaklı liderlik (8 soru) olarak üç faktördür. Liderlik davranış boyutlarından, "görev odaklı liderlik" boyutu ile ilgi 4 soru, "ilişki odaklı liderlik" boyutu ile ilgili 1 soru, "değişim odaklı liderlik" boyutu ile ilgili 4 soru, "değişime açıklık" boyutu ile ilgili 1 soru, "değişime duygusal olarak hazır olma" boyutu ile ilgili 2 soru, "değişime davranışsal ve bilişsel olarak hazır olma" boyutu ile ilgili 3 soru, 0,50 yük değerinin altında olduğu için ölçekten çıkarılmıştır. "Değişim odaklı liderlik" faktöründe yer alan bir soru, "ilişki odaklı liderlik" faktöründe analiz edilmiştir.

Bağımsız değişkenler olarak; liderlik boyutlarıyla ilgili 33 soru sorulmuş olup, faktör analizi sonucunda, liderlik boyutunu içeren toplam 24 soruyla birlikte açıklanan varyans değeri \%67,07 olarak hesaplanmıştır. Bulgular Tablo 2' de görülmektedir.

Bağımlı değişkenler olarak: Çalışanların değiş̧im kapasitesi boyutlarıyla ilgili 27 soru sorulmuş olup, faktör analizi sonucunda 21 soru ve altı faktör oluşmuştur ve açıklanan varyans değeri \%75,22 olarak hesaplanmıştır. Bulgular Tablo 3'te görülmektedir. 
Tablo 2. Liderlik Davranışı Boyutları ile Illgili Faktör Analizi

\begin{tabular}{|c|c|}
\hline Liderlik Davranışları Boyutları & Faktör Yükleri \\
\hline \multicolumn{2}{|l|}{ Görev Odaklı Liderlik (GOL) } \\
\hline GOL1-Yöneticim etkinliği arttırmak için işleri organize etti. & 0,808 \\
\hline GOL2-Yöneticim kısa dönemli faaliyetleri planladı. & 0,534 \\
\hline GOL3-Yöneticim grup veya bireylerin işlerini belirledi. & 0,732 \\
\hline GOL4-Yöneticim çalışanların rol tanımını ve görev hedeflerini belirledi. & 0,631 \\
\hline GOL5-Yöneticim kuralları, politikaları ve standart faaliyetlerin süreçlerini belirginleştirdi. & 0,698 \\
\hline GOL6-Yöneticim bölüm ya da birimlerin faaliyetlerini koordine etti. & 0,710 \\
\hline \multicolumn{2}{|l|}{ ilişki Odaklı Liderlik (iOL) } \\
\hline İOL2-Yöneticim çalışanlara zor hedefleri başarabilmeleri için güven sağladı. & 0,641 \\
\hline íOL3-Yöneticim güçlü ilişkiler sağlanması için çalışanların kaynaşmasını sağladı. & 0,642 \\
\hline iOL4-Yöneticim çalışanların sürece katkı sağlamalarına imkân tanıdı. & 0,775 \\
\hline iOL5-Yöneticim çalışanlara yol gösterici ve yardımcı oldu. & 0,650 \\
\hline ioL6-Yöneticim çalışanları etkileyecek kararlarda onlara danıştı. & 0,794 \\
\hline İOL7-Yöneticim çalışanları etkileyecek faaliyetlerde onları bilgilendirdi. & 0,645 \\
\hline iOL8-Yöneticim çatışma ve anlaşmazlıkların çözümünde çalışanlara yardımcı oldu. & 0,748 \\
\hline i̇OL9-Yöneticim takım kimlik ve bütünlüğü için seremoni, hikaye, ritüel, semboller kullandı. & 0,629 \\
\hline íL10-Yöneticim çalışanlar için örnek rol model oldu. & 0,698 \\
\hline DOL7-Yöneticim çalışanların bireysel ve ekip halinde yeni şeyler öğrenmeleri için imkân tanıdı. & 0,669 \\
\hline \multicolumn{2}{|l|}{ Değişim Odaklı Liderlik (DOL) } \\
\hline DOL1-Yöneticim değişim ihtiyaçlarının farkına vardı ve bunları açıkladı. & 0,662 \\
\hline DOL3-Yöneticim yeni fırsatlar araştırdı. & 0,671 \\
\hline DOL4-Yöneticim problem ve fırsatlara farklı açılardan bakmamız için çalışanları cesaretlendirdi. & 0,634 \\
\hline DOL8-Yöneticim yeni yaklaşımlar geliştirmek konusunda yeteneklerini gösterdi. & 0,629 \\
\hline DOL9-Yöneticim değişimin daha iyi olması için kritik pozisyondakilerle işbirliğini inşa etti. & 0,636 \\
\hline DOL10-Yöneticim değişime öncü ve rehber olacak iş gücünü oluşturdu. & 0,675 \\
\hline DOL11-Yöneticim yeni strateji ve vizyonla tutarlı sembolik değişimler yaptı. & 0,818 \\
\hline DOL13-Yöneticim değişim sürecini yönetti ve süreçle ilgili bilgilendirme yaptı. & 0,707 \\
\hline
\end{tabular}

Tablo 3. Çalışanların Değişim Kapasitesi Boyutları ile illgili Faktör Analizi

\begin{tabular}{|l|c|}
\hline Çalışanların Değişim Kapasitesi Boyutları & Faktör Yükleri \\
\hline Değişime Açıklık (DA) & 0,707 \\
\hline DA1-işimde yaşayabileceğim değişimlere karşı açık olduğumu düşünüyorum. & 0,862 \\
\hline DA3-Görevimle ilgili yapılacak değişikliği sabırsılıkla beklerim. & 0,785 \\
\hline DA4-Değişimin görevimi daha iyi yapmamda bana katkı sağlayacağını düşünürüm. & \\
\hline Değişime Direnç (DÇ) & 0,777 \\
\hline DÇ6-Genel olarak, Yürütmüş olduğum görevimin/işimin değiştirilmesine karşıyım. & 0,851 \\
\hline DÇ7-Değişimleri, yapmam gereken işler dikkate alındığında olumsuz olarak algılarım. & 0,774 \\
\hline DÇ8-Değişimler, görevimi yapmamda bana olumsuz etki yapacaktır. & \\
\hline Değişimi Problem Olarak Görme (DPG) & 0,773 \\
\hline DPG1-Değişim çoğunlukla çözümlerinden çok problem oluşturur. & 0,663 \\
\hline DPG2-Değişim çoğunlukla benim için problem oluşturur. & 0,826 \\
\hline DPG3-Değişim çoğunlukla çalışma arkadaşlarım için problem oluşturur. & 0,801 \\
\hline DPG4-Değişim çoğunlukla firmam için problem oluşturur. & \\
\hline Değişimi Risk Olarak Görme (DRG) & 0,720 \\
\hline DRG1-Yeni düşünceleri denemek risklidir. & 0,764 \\
\hline DRG2-Değişim belirsizlikle ilişkilidir. & 0,770 \\
\hline DRG3-Değişim öncesinde değişimin faydalı olacağını söylemek her zaman zordur. & \\
\hline Değişime Duygusal Olarak Hazır Olma (DDHO) & 0,777 \\
\hline DDHO1-Değişimle ilgili olumlu duygulara sahibim. & 0,848 \\
\hline DDHO2-Değiş̧imi olumlu bir süreç olarak görüyorum. & 0,847 \\
\hline DDHO3-Değişimi umut verici buluyorum. & \\
\hline
\end{tabular}


Tablo 3. Çalışanların Değişim Kapasitesi Boyutları ile Illgili Faktör Analizi (Devamı)

\begin{tabular}{|l|c|}
\hline Değişime Davranışsal ve Bilişsel Hazır Olma (DBH ve DHO) & 0,649 \\
\hline DBH4-Değişim, yapılan işleri geliştirecektir. & 0,671 \\
\hline DBH5-Değişim, yapılan işleri kolaylaştıracaktır. & 0,839 \\
\hline DHO1-Değişim sürecine hizmet etmeyi isterim. & 0,922 \\
\hline DHO2-Değişime önemli katkılar yapma konusunda istekliyimdir. & 0,894 \\
\hline DHO3-Değişim sürecine enerji katmaya istekliyimdir. & \\
\hline Toplam Açıklanan Varyans: \%75,22 & \\
\hline
\end{tabular}

Araştırmada kullanılan "liderlik davranışlarının çalışanın değişim kapasitesine etkisi" isimli anket ölçeğinin güvenilirliğini ölçmek amacıyla Cronbach Alpha katsayısından faydalanılmıştır. Yapılan güvenirlik analizi sonucunda araştırmada kullanılan veri toplama aracının güvenilir bir ölçme aracı olduğu sonucuna ulaşılmıştır. Tablo 4'te görüleceği üzere alfa değerleri 0,77 ile 0,94 arasında olup değişkenler genel olarak içsel tutarlılığa sahiptir. Bulgular Tablo 4'te görülmektedir.

Tablo 4. Güvenilirlik Analizi Sonuçları

\begin{tabular}{|l|c|c|c|c|}
\hline DEĞişKENLER & Soru sayısı & Ortalama & $\begin{array}{c}\text { Standart } \\
\text { Sapma }\end{array}$ & $\begin{array}{c}\text { Alfa ( } \boldsymbol{\alpha}) \\
\text { Katsayısı }\end{array}$ \\
\hline Görev Odaklı Liderlik & 6 & 3,59 & 0,75 & 0,88 \\
\hline ilişki Odaklı Liderlik & 10 & 3,31 & 0,96 & 0,94 \\
\hline Değişim Odaklı Liderlik & 8 & 3,48 & 0,84 & 0,92 \\
\hline Değişime Açıkık & 3 & 3,70 & 0,80 & 0,92 \\
\hline Değişime Direnç & 3 & 3,00 & 0,96 & 0,78 \\
\hline Değişime Değişimi problem olarak görme & 4 & 2,52 & 0,87 & 0,88 \\
\hline Değişime Risk olarak görme & 3 & 2,77 & 0,93 & 0,77 \\
\hline Değişime Duygusal Olarak Hazır Olma & 3 & 3,59 & 0,87 & 0,90 \\
\hline Değişime Davranışsal ve Bilişsel Hazır Olma & 5 & 3,26 & 0,70 & 0,88 \\
\hline
\end{tabular}

Tablo 5'te liderlik davranışları boyutları ile değişim kapasitesi boyutları arasındaki ilişkiler $p<0,01$ ve $p<0,05$ anlamlılık düzeylerinde çift taraflı olarak sınanmıştır. Tablo 5'e göre; modeldeki değişkenlere ait Pearson korelasyon katsayıları, ortalama ve standart sapma göstergeleri verilmiştir. Değişkenlere ait standart sapma değerleri 0,75 ile 0,96 arasında hesaplanmış olup, bu değerler arasındaki varyans (değişkenlik) miktarının, geçerli analiz yapılması için yeterli seviyede olduğunu göstermektedir.

Tablo 5'te yer alan Liderlik davranış boyutları arasında en yüksek ilişki “Değişim Odaklı Liderlik" ile "ilişki Odaklı Liderlik" boyutları arasında pozitif korelasyon $p<0,01(0,869)$ düzeyinde anlamlı iken, en düşük ilişki ise "Değişim Odaklı Liderlik" ile "Değişime Açıklık" arasında pozitif korelasyon $p<0,01(0,214)$ düzeyinde anlamlıdır. "Görev Odakı Liderlik" boyutunun çalışanın değişim kapasitesi ile anlamlı bir ilişkisi olmadığı, "ilişki Odaklı Liderlik" boyutunun değişim kapasitesi boyutlarından "Değişime davranışsal ve bilişsel olarak hazır olma" ile pozitif olarak ilişkili olduğu, "Değişim Odaklı Liderlik" boyutunun ise değişim kapasitesi boyutlarından "Değişime Açıklık", "Değişime Duygusal Olarak Hazır Olma” ve "Değiş̧ime Davranışsal ve Bilişsel Olarak Hazır Olma" boyutları ile pozitif ilişkili olduğu saptanmıştır.

Tablo 5'te tüm değişkenlere ilişkin ortalama, standart sapma ve değişkenler arası korelasyon analizine yer verilmiştir. Değişkenler arasındaki korelasyon sonuçlarına bakıldığında; "Değişime açıklık" ile "Değişimi problem olarak görme" arasında $p<0,05(-0,217)$ seviyesinde negatif ilişki olduğu, "Değişimi problem olarak görme" ve "Değişimi risk olarak görme " arasında $p<0,01(0,604)$ seviyesinde pozitif ilişki görülmektedir. Çalışanın değişime duygusal hazır olması, çalışanın değişimi problem olarak görme $p<0,01(-0,455)$ ve riskli görme ile $p<0,01(-0,339)$ negatif ilişkisi görülmektedir. 
Tablo 5. Korelasyon Tablosu

\begin{tabular}{|c|c|c|c|c|c|c|c|c|c|c|c|c|}
\hline & & Ort & Std & $\alpha$ & 1 & 2 & 3 & 4 & 5 & 6 & 7 & 8 \\
\hline 1 & $\begin{array}{l}\text { Görev Odaklı } \\
\text { Liderlik }\end{array}$ & 3,59 & ,75 & 88 & 1 & & & & & & & \\
\hline 2 & İlişki Odaklı Liderlik & 3,31 & 96 & ,94 & ,747** & 1 & & & & & & \\
\hline 3 & $\begin{array}{l}\text { Değişim Odaklı } \\
\text { Liderlik }\end{array}$ & 3,48 & ,84 & ,92 & ,736** &, $869 * *$ & 1 & & & & & \\
\hline 4 & Değişime Açıklık & 3,70 & ,80 & ,92 & 076 & 103 &, $214 *$ & 1 & & & & \\
\hline 5 & Değişime Direnç & 3,00 & 96 & ,78 & ,054 & ,068 &,- 016 &,- 066 & 1 & & & \\
\hline 6 & $\begin{array}{l}\text { Problem olarak } \\
\text { görme }\end{array}$ & 2,52 & 87 & ,88 &,- 050 &,- 004 &,- 187 & , $217^{-}$ &, $362 * *$ & 1 & & \\
\hline 7 & Risk olarak görme & 2,77 & ,93 & 77 &,- 023 &,- 014 &,- 016 &,- 053 &, $365 * *$ &, $604 * *$ & 1 & \\
\hline 8 & Duygusal Hazırlık & 3,59 & 87 & 90 & ,096 & 145 & ,300** & 185 &,- 184 & $\begin{array}{c}- \\
, 455^{* *}\end{array}$ & $\begin{array}{c}- \\
, 339 * *\end{array}$ & 1 \\
\hline 9 & $\begin{array}{l}\text { Davranışsal ve } \\
\text { Bilişsel Hazırlık }\end{array}$ & 3,26 & 70 & 88 & ,076 & ,231** &, $224 * *$ &,- 006 &,- 174 &,- 174 &,- 166 & ,496** \\
\hline
\end{tabular}

\subsection{Regresyon Analizi ve Hipotez Testleri}

Araştırma kapsamındaki hipotezleri test etmek için çoklu regresyon analizi kullanılmıştır. Çoklu regresyon analizinin amacı regresyon denkleminin parametrelerinin değerlerini saptamaktır (íslamoğlu ve Alnıaçık, 2013). Araştırma kapsamındaki tüm modeller SPSS 16 istatistik paket programı ile analiz edilmiştir ve elde edilen sonuçlar ve hipotezlerin testi, aşağıda sırası ile açıklanmaktadır.

Liderlik davranış boyutlarının (görev odakı liderlik, ilişki odaklı liderlik, değişim odaklı liderlik) çalışanların değişim potansiyeline (değişime açıklık, değişime direnç, değişimi problem görme, değişimi risk görme, değişime duygusal, davranışsal ve bilişsel hazır olma) yordama derecesini belirlemek için yapılan çoklu regresyon analizi sonuçları Tablo 6'da verilmiştir.

Tablo 6. Regresyon Analizi Tablosu

\begin{tabular}{|c|c|c|c|c|c|c|c|c|c|c|c|c|}
\hline \multirow{2}{*}{$\begin{array}{l}\text { Bağımlı } \\
\text { Değişkenler }\end{array}$} & \multicolumn{2}{|c|}{$\begin{array}{c}\text { Model } 1 \\
\text { Değişime Açıklık }\end{array}$} & \multicolumn{2}{|c|}{$\begin{array}{l}\text { Model } 2 \\
\text { Değişime } \\
\text { Direnç }\end{array}$} & \multicolumn{2}{|c|}{$\begin{array}{c}\text { Model } 3 \\
\text { Değişimi } \\
\text { Problem Olarak } \\
\text { Görme }\end{array}$} & \multicolumn{2}{|c|}{$\begin{array}{l}\text { Model } 4 \\
\text { Değişimi } \\
\text { Risk Olarak } \\
\text { Görme }\end{array}$} & \multicolumn{2}{|c|}{$\begin{array}{c}\text { Model } 5 \\
\text { Duygusal Olarak } \\
\text { Hazır Olma }\end{array}$} & \multicolumn{2}{|c|}{$\begin{array}{c}\text { Model } 6 \\
\text { Davranışsal ve } \\
\text { Bilişsel Hazır } \\
\text { Olma }\end{array}$} \\
\hline & $\beta$ & $\mathrm{t}$ & $\beta$ & $\mathrm{t}$ & $\beta$ & $\mathrm{t}$ & $\beta$ & $\mathrm{t}$ & $\beta$ & $\mathrm{t}$ & $\beta$ & $\mathrm{t}$ \\
\hline $\begin{array}{l}\text { Görev Odaklı } \\
\text { Liderlik (a) }\end{array}$ & $\begin{array}{c}- \\
098\end{array}$ &,- 699 & ,089 & ,604 & ,056 & ,409 & $\begin{array}{c}- \\
, 023\end{array}$ & $\begin{array}{c}- \\
160\end{array}$ & $\begin{array}{c}- \\
160\end{array}$ & $-1,175$ & $\begin{array}{c}- \\
154\end{array}$ & $-1,119$ \\
\hline $\begin{array}{l}\text { İlişki Odaklı } \\
\text { Liderlik (b) }\end{array}$ & $\begin{array}{c}- \\
173 \\
\end{array}$ & $-1,000$ & 214 & 1,205 & ,417 & $2,455^{*}$ & ,004 & ,025 & $\begin{array}{c}- \\
, 235\end{array}$ & $-1,400$ & 399 & $2,350^{*}$ \\
\hline $\begin{array}{l}\text { Değişim } \\
\text { Odaklı Liderlik }\end{array}$ & ,422 & $2,412^{*}$ & $\begin{array}{c}- \\
, 254\end{array}$ & $-1,375$ & $\begin{array}{c}- \\
\text {,565 }\end{array}$ & $\begin{array}{c}- \\
3,291 * *\end{array}$ & , & , & 602 & $3,548 * *$ & ,062 & ,360 \\
\hline $\begin{array}{c}F \\
R^{2} \\
\text { Düzeltilmiş } R^{2}\end{array}$ & & $\begin{array}{l}19 * \\
065 \\
037\end{array}$ & & $\begin{array}{l}39 \\
23 \\
066\end{array}$ & & $\begin{array}{l}67 * * \\
102 \\
075\end{array}$ & & & & $\begin{array}{l}91 * * \\
131 \\
105\end{array}$ & & $\begin{array}{l}38 * * \\
128 \\
102\end{array}$ \\
\hline
\end{tabular}

Tablo 6'da yer alan Model 2 ve Model 4 regresyon analizi doğrultusunda $\mathrm{H} 2_{a, b, c}$ ve $H 4_{a, b, c}$ hipotezlerinin desteklenmediği sonucuna ulaşılmıştır. Bulgular doğrultusunda, Tablo 6'ya göre, liderlik davranışlarının değişime açıklık üzerindeki etkisinin araştıııldığı Model 1, istatistiksel olarak anlamlı bulunmuştur $(F=2,319 ; p<0,01)$. Regresyon analizi sonucunda liderlik davranışlarından değişim odaklı liderliğin $(2,412 ; p<0,01)$ değişime açık olmayı pekiştirdiği görülmektedir. Görev odaklı liderliğin ve Ilişski odaklı liderliğin çalışanların değişime açık olma potansiyellerine bir etkisi görülmemektedir. Bu bulgular doğrultusunda, $\mathrm{H} 1_{c}$ hipotezi desteklenirken, $\mathrm{H}_{\mathrm{a}, \mathrm{b}}$ hipotezleri desteklenememiştir. 
Tablo 6'ya göre, liderlik davranışlarının, çalışanların değişimi problem olarak görme potansiyeli üzerindeki etkisinin araştırıldığı Model 3 , istatistiksel olarak anlamlı bulunmuştur $(F=3,767 ; p<0,01)$. Regresyon analizi sonucunda liderlik davranışlarından ilişki odaklı liderliğin $(2,445 ; p<0,01)$ çalışanların değişimi problem olarak görme potansiyelini pekiştirdiği, değişim odaklı liderliğin ise çalışanların değişimi problem olarak görme potansiyelini azalttığı görülmektedir $(-3,291 ; p<0,01)$. Görev odaklı liderliğin, çalışanların değişimi problem olarak görme potansiyeline bir etkisi görülmemektedir. Bu bulgular doğrultusunda, $\mathrm{H} 3_{b, c}$ hipotezleri desteklenirken, $\mathrm{H}_{\mathrm{a}}$ hipotezi desteklenememiştir.

Tablo 6'ya göre, liderlik davranışlarının, çalışanların değişime duygusal olarak hazır olma potansiyeli üzerindeki etkisinin araştırıldığı Model 5, istatistiksel olarak anlamlı bulunmuştur $(F=4,991 ; p<0,01)$. Regresyon analizi sonucunda liderlik davranışlarından değişim odaklı liderliğin $(2,445 ; p<0,01)$ çalışanların değişime duygusal olarak hazır olma potansiyelini pekiştirdiği, görev odaklı liderlik ile ilişki odaklı liderliğin ise çalışanların değişime duygusal olarak hazır olma potansiyeline bir etkisi olmadığı gözlemlenmiştir. Bu bulgular doğrultusunda, $\mathrm{H} 5_{\mathrm{c}}$ hipotezi desteklenirken, $\mathrm{H} 5_{\mathrm{a}, \mathrm{b}}$ hipotezleri desteklenememiştir.

Tablo 6'ya göre, liderlik davranışlarının, çalışanların değişime davranışsal ve bilişsel olarak hazır olma potansiyeli üzerindeki etkisinin araştırıldığı Model 6 , istatistiksel olarak anlamlı bulunmuştur $(F=4,938$; $p<0,01)$. Regresyon analizi sonucunda liderlik davranışlarından ilişki odaklı liderliğin $(2,350 ; p<0,01)$ çalışanların değişime davranışsal ve bilişsel olarak hazır olma potansiyelini pekiştirdiği, görev odaklı liderlik ile değişim odaklı liderliğin ise çalışanların değişime davranışsal ve bilişsel olarak hazır olma potansiyeline bir etkisi görülmemektedir. Bu bulgular doğrultusunda, $H 6_{b}$ hipotezi desteklenirken, $H 6_{a, c}$ hipotezleri desteklenememiştir.

\section{Sonuç}

Araştırma verilerinden elde edilen sonuçlara göre (Tablo 4 ve Tablo 5), görev odaklı liderlik davranışı, çalışanların değişim kapasitesi üzerinde anlamlı bir etkiye sahip değildir. Görev odaklı liderlerin davranışları genel hatları ile ele alındığında bu yaklaşım özellikle kısa dönemli işleri planlama, işleri ve çalışanların görev ve sorumluluklarına açıklık getirme, faaliyetleri ve performansı kontrol etmeyi içerdiğinden organizasyonların özellikle birleşme ve satın alma gibi köklü değişimlerin yaşandığı dönemlerde görev odaklı liderlik davranışların çalışanın değişim kapasitesine etkisinde öne çıkan bir liderlik davranışı olmayacağı görülmektedir (Yukl, 2010).

ilişski odaklı liderlik davranışı çalışanın davranışsal ve bilişsel olarak değişime hazır olma potansiyelini güçlendirmektedir. Fakat ilişki odaklı liderlik, çalışanın değişimi problem olarak algılamasına neden olmaktadır. İlişki odakıı liderlik davranışı ile çalışanların değişime ilişkin davranışsal ve bilişsel farkındalıkları beslenerek, değişime iliş̧in tutumları olumlu yönde etkilenecektir. İlişki odaklı liderin değişim sonuçlarının çalışana neler getireceği veya ne zorluklar oluşturacağını, değişime çalışanın nasıl katkıda bulunacağını, nasıl eylemler gerçekleştirmesi gerekmesini açıklayacak, destekleyecek faaliyetler yürütmelidir. Yöneticilerin ilişki odaklı lider davranışları sergileyerek, değişim sürecinde çalışanın duygusal hazır olmasına negatif etki etmektedir. Iliş̧ki odaklı liderin çalışanı değişim sürecinde duygusal olarak hazır hazırlamasına yönelik eylemleri çalışan açısından gelecek kaygılarını azaltmayacağı, aksine artıracağı görülmektedir.

Değişim odaklı liderlik davranışı ise, çalışanların değişime açık olma ve duygusal olarak hazır olma potansiyelini kuvvetlendirmekle beraber değişime olumsuz bakışını azalttığı görülmektedir. Araştırma verilerinden elde edilen sonuçlara göre (Tablo-4) değişime duygusal olarak hazır olmak, değişime olumsuz bakışı azaltıp, çalışanların değişim potansiyellerini olumlu etkileyebilmektedir. Değişime davranışsal ve bilişsel hazır olma ile duygusal hazır olma arasında doğru orantılı bir ilişki vardır.

Görev odaklı yaklaşım, çalışanın görev ve sorumluluklarının belirgin olmasını, iş tatmini ve iş performansı üzerinde belirleyici olmaktadır (Özdevecioğlu ve Kanıgür, 2009). Oysa ki değişim sürecinde, çalışanların mevcut değerler ve örgütsel yaşam tarzlarına yönelik kendilerini tedirgin eden birçok tehdit algısı oluşmuştur. Çalışanların bu durumla başa çıkarak değişim sürecine katkıda bulunmaları için alışıla gelmiş faaliyetleri daha etkin hale getirme veya iyileştirme anlayışı yerine, vizyona, heyecana ve değişimin gerekliliğine inanmaya, intiyaçları vardır. ilişki ve görev odaklı liderlerin, daha çok bireysel veya grup düzeyindeki hedeflerin, örgütün yapısal hedefleri ile aynı olduğunu varsaymaları, değişime yönelik çabaların başarıya ulaşmasında en temel sorunlardan biri olmuştur (Barnard ve Stoll, 2010). 
Çalışanların duygusal olarak değişime hazır olmaları önemlidir. Liderin duygusal desteğini alan üyeler kendilerini güvende hissederler, organizasyona karşı sadık, lidere karşı saygılı ve işlere karşı motive olmuşlardır (Ergün, 2018). Yönetimdeki güvenin; duyusal, bilişsel ve davranışsal direnç üzerinde oldukça güçlü bir etkisi olduğu tespit edilmiştir (Özdevecioğlu ve Kanıgür, 2009). Değişim odaklı liderlik davranışı, çalışanın duygusal kapasite boyutunu ve değişime açık olma potansiyelini besleyerek, değişime ilişkin tutumları olumlu yönde etkiler. Değişim odaklı liderler, kararlı ve risk alan yapıları, duygudaşlık yetenekleri, hayranlık uyandıran davranışları, güçlendirici ve ilham veren tutumları ile yaratıcı düşünceyi özendirerek, çalışanların değişime ilişkin tutumlarını ve motivasyonlarını etkiler. Böylece çalışanların değişim kapasitelerini artıır ve hatta değişime karşı olan olumsuz tutumlarının değişmesine neden olurlar.

Gelecek çalışmalarda farklı sektörler incelenerek ya da çalışmanın bir coğrafi bölgeyi veya ülke genelini temsil edebilecek şekilde geliştirilmesi uygun olabilir. Özellikle eğitim, sağlık gibi farklı sektörlerde liderlik davranışlarının çalışanın değişime hazır olması yönelik tutumları incelenebilir. Aynı zamanda bu araştırmada kullanılan veriler, araştırmacı tarafından hazırlanan veri toplama aracına, örgüt çalışanlarının verdikleri yanıtlardan elde edilen bilgilerle sınırlıdır.

\section{Kaynaklar}

Akın, G., Özer, B. K., \& Gültekin, T. (2004). İnsan evrim sürecine ait bir hipotezin değerlendirilmesi. Ankara Üniversitesi Dil ve Tarih-Coğrafya Fakültesi Dergisi, 44(1), 111-124.

Alparslan, A. M., \& Oktar, Ö. F. (2015). Türkiye'de lider-üye etkileşim kuramına dair makale kapsamındaki araştırmalar: Bibliyometrik bir içerik analizi. Business and Economics Research Journal, 6(1), 107-123.

Armenakis, A. A., Harris, S. G., \& Mossholder, K. W. (1993). Creating readiness for organizational change. Human Relations, 46(6), 681-703.

Armenakis, A. A., Harris, S. G., \& Feild, H. S. (2000). Making change permanent: A model for institutionalizing change interventions. In W. A. Pasmore \& R. W. Woodman (Eds.), Research in organizational change and development (pp. 97-128). Emerald Group Publishing Limited.

Avolio, B. J., \& Bass, B. M. (1988). Transformational leadership, charisma, and beyond. In J. G. Hunt, B. R. Baliga, H. P. Dachler, \& C. A. Schriesheim (Eds.), International leadership symposia series. Emerging leadership vistas (pp. 2949). Lexington, MA, England: Lexington Books/D. C. Heath and Com.

Avolio, B. J., \& Bass, B. M. (Eds.). (2001). Developing potential across a full range of Leadership Tm: Cases on transactional and transformational leadership. Psychology Press.

Bakan, I.., \& Büyükbeşe, T. (2010). Liderlik türleri ve güç kaynaklarına ilişkin mevcut-gelecek durum karşılaştırması. Karamanoğlu Mehmet Bey Üniversitesi Sosyal ve Ekonomik Araştırmalar Dergisi, 2, 73-84.

Barnard, M., \& Stoll, N. (2010). Organisational change management: A rapid literature review. Short Policy Report No. 10/01 Centre for Market and Public Organisation Bristol Institute of Public Affairs University of Bristol.

Basım, H. N., Korkmazyürek, H., \& Tokat, A. O. (2008). Çalışanların öz yeterlilik algısının yenilikçilik ve risk alma üzerine etkisi kamu sektöründe bir araştırma. Selçuk Üniversitesi Sosyal Bilimler Enstitüsü Dergisi, 19, 121-130.

Baumgartner, E., \& Strayer, F. F. (2008). Beyond flight or fight: Developmental changes in young children's coping with peer conflict. Acta Ethologica, 11(1), 16-25.

Boga, I., \& Ensari, N. (2009). The Role of transformational leadershipand organizational change on perceived organizational success. The Psychologist-Manager Journal, 12, 235-251.

Bouckenooghe, D., Devos, G., \& Van Den Broeck, H. (2009). Organizational change questionnaire-Cclimate of change, processes, and readiness: Development of a new instrument. The Journal of Psychology, 143(6), 559-599.

Cömert, M. (2004). Dönüşümcü liderlik. XIII. Ulusal Eğitim Bilimleri Kurultayı. İönü Üniversitesi, Eğitim Fakültesi.

Çolakoğlu, M. (2005). Eğitim örgütlerinde değişim ve liderlik. Hasan Ali Yücel Eğilim Fakültesi Dergisi, 2(1), 63-77.

Demirtaş, H. (2012). Primary schools' openness to change. Elementary Education Online, 11(1), 18-34.

Dunham, R.B., Grube, J.A., Gardner, D.G., L. L., Cummings, L.L., \& Pierce, J.L. (1989). The development of an attitude toward change instrument. Paper presented in Annual Academy of Management Conference, Madison, WI.

Elizur, D., \& Guttman, L. (1976). The structure of attitudes toward work and technological change within an organization. Administrative Science Quarterly, 611-622. 
Ekvall, G., \& Arvonen, J. (1991). Change-centered leadership: An extension of the two-dimensional model. Scandinavian Journal of Management, 7, 17-26.

Ergün, E., \& Arslantürk, E. H (2016). The effects of leadership behaviours on organizational change: The mediating role of person-organization fit. Eurasian Academy of Sciences, Eurasian Business \& Economics Journal, 2(1), 1-13.

Ergün, E., \& Çelik, S. (2015). Yöneticilerin görev ve çalışan odaklı liderlik davranışları ve hemşirelerin iş tatmini, örgütsel bağıılığı ve iş stresi arasındaki ilişki. Florence Nightingale Dergisi, 23(3), 203-214.

Ergün, E. (2018) Lider desteğinin lider üye etkileşimine (LÜE) ve iş tatminine etkileri. Atatürk Üniversitesi İktisadi İdari Bilimler Dergisi, 32(1), 177-193.

İslamoğlu, H., \& Alnıaçık, Ü. (2013). Sosyal bilimlerde araştırma yöntemleri. Beta Yayınları.

Kavanagh, M. H., \& Ashkanasy, N. M. (2006). The impact of leadership and change management strategy on organizational culture and individual acceptance of change during a merger. British Journal of Management, 17(1), 81-103

Kayasandık, A. E. (2017). Öğretmenlerin bireysel yenilikçilik ve değişime hazır olmalarının algılanan örgütsel destek ile ilişkisi: Samsun'da bir çalışma. Akademik Sosyal Araştırmalar Dergisi, 5(5), 511-527.

Kirrane, M., Lennon, M., O'Connor, C., \& Fu, N. (2017). Linking perceived management support with employees' readiness for change: The mediating role of psychological capital. Journal of Change Management, 17(1), 47-66.

Kondakçı, Y., Zayim, M., \& Çalışkan, Ö. (2013). Development and validation of readiness for change scale. ilköğretim Online, 12(1), 23-35.

Luthans, F. (2010). Organizational behavior: An evidence-based approach (12th Edition). McGraw-Hill Book Company.

Oreg, S. (2003). Resistance to change: Developing an individual differences measure. Journal of Applied Psychology, 88(4), 680-694.

Özmutaf, M. N. (2007). Liderliğin örgüt kültürü içinde değişimsel boyutta değerlendirilmesi. Süleyman Demirel Üniversitesi Sosyal Bilimler Enstitüsü Dergisi, 2(2), 83-98.

Özdevecioğlu, M., \& Kanıgür, S. (2009). Çalışanların ilişki ve görev yönelimli liderlik algılamalarının performansları üzerindeki etkileri. Karamanoğlu Mehmet Bey Üniversitesi Sosyal ve Ekonomik Araştırmalar Dergisi, 1, 53-82.

Rafferty, A.E., \& Griffin, M.A. (2006). Perceptions of organizational change: A stress and coping perspective. Journal of Applied Psychology, 91(5), 1154-1162.

Rafferty, A. E., Jimmieson, N. L., \& Armenakis, A. A. (2013). Change readiness: A multilevel review. Journal of Management, 39(1), 110-135.

Saylı, H. (2008). Başarılı bir örgütsel değişimin gerçekleştirilmesinde dönüştürücü liderliğin rolü. Erciyes Üniversitesi İktisadi ve İdari Bilimler Fakültesi Dergisi, 30(1), 193-210.

Schein, E. H. (2010). Organizational culture and leadership (2.ed.). John Wiley \& Sons.

Soydemir, S., Özdaşlı, K., \& Alpaslan A. M. (2014). Görev-insan odaklı liderlik algısının vatandaşa yönelik prososyal hizmet davranışlarına etkisi: Kolluk kuvvetleri üzerine bir araştırma. Afyon Kocatepe Üniversitesi İktisadi ve İdari Bilimler Fakültesi Dergisi, 16(2), 63-81.

Taş, A., \& Önder, E. (2010). Yöneticilerin liderlik davranışlarının personel iş doyumuna etkisi. Elektronik Sosyal Bilimler Dergisi, 9(32), 17-30.

Tekin, E. (2018). Lider-üye etkileşiminin örgütsel vatandaşlık davranışı üzerindeki etkisinde örgütsel adalet algısının aracılık rolü. Business Management International Journal, 6(1), 291-314.

Tunçer, P. (2011). Örgütsel değişim ve liderlik. Sayıştay Dergisi, 80(1), 57-83

Vakola, M., \& Nikolaou, I. (2005). Attitudes towards organizational change: What is the role of employees' stress and commitment? Employee Relations, 27(2), 160-174.

Velasquez, M. G., \& Velazquez, M. (2002). Business ethics: Concepts and cases (Vol. 111). Upper Saddle River, NJ: Prentice Hall.

Yukl, G. (1999). An evaluative essay on current conceptions of effective leadership. European Journal of Work and Organizational Psychology, 8(1), 33-48.

Yukl, G. (2010). Leadership in organizations (7th Edition). New Jersey: Prentice Hall.

Yukl, G. (2012). Effective leadership behavior: What we know and what questions need more attention. Academy of Management Perspectives, 26(4), 66-85. 